\title{
Monika Michalak
}

Uniwersytet Mikołaja Kopernika, Toruń

moniqa1988@o2.pl

\section{Należyta staranność i dobra wiara w orzecznictwie Trybunału Sprawiedliwości Unii Europejskiej oraz polskich sądów administracyjnych}

DOI: http://dx.doi.org/10.12775/SIT.2016.021

\section{Wstęp}

Przedmiotem artykułu jest problem pojmowania należytej staranności oraz dobrej wiary w podatku od towarów i usług ${ }^{1}$. W polskiej Ustawie $z$ dnia 11 marca 2004 r. o podatku od towarów i usług ${ }^{2}$ (dalej: podatek VAT) brak definicji zarówno należytej staranności, jak i dobrej wiary. Definicji tych nie znajdziemy również w przepisach unijnych, szczególnie w Dyrektywie 2006/112/WE z dnia 28 listopada 2006 r. ${ }^{3} \mathrm{w}$ sprawie wspólnego systemu podatku od wartości dodanej. Wobec braku definicji obu pojęć TSUE zdecydował się na zdefiniowanie należytej staranności i dobrej wiary w swoich orzeczeniach. Problem ten powoduje u podatników i organów podatkowych niepewność co do prawidłowego rozumowania obu pojęć.

Artykuł ten wskazuje jedynie oba pojęcia w kontekście prawa do odliczenia, nie odnosząc się m.in. do zwolnienia dostawy we-

\footnotetext{
${ }^{1} \mathrm{~W}$ ustawodawstwie unijnym jako podatek od wartości dodanej.

2 Dz.U. z 2004 r. Nr 54, poz. 535 z zm.

${ }^{3}$ Dz.Urz. UE L z 2006 r. nr 347/ 1 z zm.
} 
wnątrzwspólnotowej towarów, zwolnienia $z$ tytułu dostaw towarów wywożonych poza terytorium Unii Europejskiej, odpowiedzialności solidarnej oraz korekty podatku wykazanego na fakturze.

Oba pojęcia wielokrotnie były już wyjaśniane zarówno przez Trybunał Sprawiedliwości Unii Europejskiej (dalej: TSUE, Trybunał), jak i w ślad za nim przez polskie sądy administracyjne, zarówno Wojewódzkie Sądy Administracyjne (dalej: WSA), jak i Naczelny Sąd Administracyjny (dalej: NSA).

„TSUE rozważał zagadnienie dobrej wiary w następujących obszarach: prawo do obliczenia VAT, zwolnienie dostawy wewnątrzwspólnotowej towarów, zwolnienie $z$ tytułu dostaw towarów wywożonych poza terytorium Unii Europejskiej, odpowiedzialność solidarna oraz korekta podatku wykazanego na fakturze"4.

Oba pojęcia przede wszystkim warunkują prawo do odliczenia podatku należnego. „Prawo do odliczenia stanowi integralną część mechanizmu VAT i co do zasady, nie podlega ograniczeniu"'. Dzięki nim podatnicy mogą bronić się przed zarzutem udziału w oszustwach podatkowych (nazywanych potocznie karuzelami podatkowymi) w razie podejrzenia wystąpienia nieprawidłowości u kontrahentów i próby wyłudzenia podatku VAT. Prawo to decyduje również o tym, iż podatek VAT jest podatkiem neutralnym i dopiero na końcowym etapie jest zapłacony przez konsumenta.

\section{Pojęcie dobrej wiary}

Pojęcie dobrej wiary pojawiła się już za czasów prawa rzymskiego. Była ona rozumiana jako miara etyczna, miara postępowania w konkretnych stosunkach prawnych. Dobra wiara oznaczała również

${ }^{4}$ D. Dominik-Ogińska, Dobra wiara $w$ podatku od wartości dodanej $w$ orzecznictwie Trybunału Sprawiedliwości Unii Europejskiej (1), „Przegląd Prawa Podatkowego" 2013, nr 7, s. 29.

${ }^{5}$ M. Militz, Nowe aspekty badania dobrej wiary u nabywców paliw, „Przegląd Podatkowy” 2014, nr 8, s. 6. Por. także wyrok TSUE z dnia 21 czerwca 2012 r. w sprawach połączonych C-80/11 Mahagében kft i C-142/11 Péter Dávid, http://curia.europa.eu/juris/document/document.jsf?docid=124187\&doclang=PL (dostęp: 01.06.2016 r.). 
zaufanie stron, a także wyrażana była przez zasadę słuszności i sprawiedliwości ${ }^{6}$. Oznaczała zgodność postępowania kontrahentów z ówczesnym prawem. Wobec tego bona fides była klauzulą słuszności. Do niej dostosowywali swoje stosunki kontraktowe strony.

W literaturze przedmiotu wskazuje się na dwie podstawowe funkcje dobrej wiary. Pierwsza polegała na pełnieniu przez nią funkcji ochronnej w stosunkach prawnych, natomiast druga na pełnieniu funkcji tzw. klauzuli słuszności ${ }^{7}$.

\section{Pojęcie należytej staranności}

Definicji należytej staranności zazwyczaj poszukuje się w obecnym prawie cywilnym w art. 355 k.c. ${ }^{8}$, gdzie zresztą należała do najbardziej spornych kwestii w doktrynie prawa cywilnego ${ }^{9}$. Wskazuje się w $\S 1$ art. 355 k.c., że „dłużnik obowiązany jest do staranności ogólnie wymaganej w stosunkach danego rodzaju (należyta staranność)”. W § 2 cytowanego artykułu ustawodawca wskazał, że „należytą staranność dłużnika w zakresie prowadzonej przez niego działalności gospodarczej określa się przy uwzględnieniu zawodowego charakteru tej działalności”. W komentarzu do art. 355 k.c. na pierwszy plan wysuwa się, że „przez należytą staranność rozumiemy [...], określony sposób postępowania mającego prowadzić do spełnienia świadczenia; pewien model, wzorzec skonstruowany $z$ reguł postępowania (powinności)" ${ }^{10}$.

Należyta staranność i dobra wiara są ze sobą powiązane. W stanie dobrej wiary jest bowiem osoba, która powinna dołożyć należytej staranności. „Staranność wiążę się zawsze z momentem jej oceny,

${ }^{6}$ K. Doliwa, Dobra wiara jako wyrażenie języka prawnego, „Monitor Prawniczy" 2008, nr 6, s. 302.

7 Ibidem, s. 303. Rzymska paremia: Ius est ars boni et aequi - „Prawo jest sztuką stosowania tego, co dobre i słuszne” (Celsus).

${ }^{8}$ Dz.U. z 1964 r. Nr 16, poz. 93 z zm (dalej: k.c.).

9 Z. Banaszczyk, P. Granecki, O istocie należytej staranności, „Palestra” 2002, nr 7-8, s. 13.

10 P. Machnikowski, w: Kodeks cywilny. Komentarz, red. E. Gniewek, P. Machnikowski, Warszawa 2013, s. 555. 
a więc jest uwarunkowana czasowo, $\mathrm{z}$ rodzajem stosunku prawnego, a więc jest uwarunkowana przedmiotowo, $z$ wolą stron, jest więc uwarunkowana podmiotowo. Nie istnieje więc jakiś absolutny obowiązek staranności dostosowania do stosunków danego rodzaju. [...] Różne rodzaje zobowiązań dyktują też różny stopień staranności” ${ }^{11}$. Strony powinny w swoich stosunkach dochować należytej staranności, aby ich stosunki ułożyły się w sposób prawidłowy. Nie można bowiem wierzyć kontrahentowi ponad wszystko, trzeba mieć podstawę do zawarcia umowy i zachować minimum środków ostrożności, a więc sprawdzić, $z$ kim zawieramy kontrakt oraz skąd m.in. pochodzą oferowane przez niego towary.

\section{Wyroki TSUE i polskich sądów administracyjnych}

\subsection{Orzeczenia TSUE}

Od wielu lat TSUE w niejednej sprawie przedstawiał kwestie należytej staranności oraz dobrej wiary. Trybunał starał się wyjaśnić oba pojęcia, aby w sposób prawidłowy mogły być stosowane zarówno przez podatników, jak i organy podatkowe państw Unii Europejskiej. Oczywiście wyroki, zaprezentowane w dalszej części, zapadły na podstawie konkretnego stanu faktycznego, który nie został rozstrzygnięty przez sąd krajowy. Wobec tego sąd krajowy w razie wątpliwości zwraca się do TSUE $z$ wnioskiem o rozpatrzenie pytania prejudycjalnego, oczywiście pod warunkiem uznania, że pytanie to ma wpływ na wynik sprawy głównej.

W pierwszej $z$ wielu spraw, w którym TSUE zwrócił uwagę na dobrą wiarę, był wyrok zapadły w połączonych sprawach C-354/03 Optigen Ltd, C-355/03 Fulcrum Electronics Ltd i C-484/03 Bond House Systems Ltd v. Commissioners of Customs ${ }^{12}$. Działalność spółek Optigen, Fulcrum oraz Bond House polegała głównie na

${ }^{11}$ M. Sośniak, Należyta staranność, Katowice 1980, s. 125.

12 Wyrok TSUE $z$ dnia 12 stycznia 2006 r. w sprawach połączonych C-354/03 Optigen Ltd, C-355/03 Fulcrum Electronics Ltd i C-484/03 Bond House Sys- 
nabywaniu mikroprocesorów od spółek mających siedziby w Zjednoczonym Królestwie i ich dalszej odsprzedaży nabywcom mającym siedziby w innym państwie członkowskim. Wszystkie trzy spółki zażądały zwrotu nadwyżki podatku naliczonego nad należnym, który został zakwestionowany przez organy podatkowe. Transakcje wykonywane przez spółki Optigen, Fulcrum oraz Bond House stanowiły część łańcucha dostaw. Organy podatkowe wskazały, że na wcześniejszych etapach nie został uregulowany podatek VAT przez podmiot, który następnie zniknął z rynku, albo przez podmiot posługujący się przywłaszczonym numerem identyfikacji podatkowej VAT. Wobec tego uznawano, że spółki Optigen, Fulcrum oraz Bond House brały udział w oszustwach podatkowych.

W wyroku tym TSUE w pkt 52 odniósł się również do prawa do odliczenia, wskazując, że „prawo podatnika dokonującego takich transakcji do odliczenia naliczonego podatku VAT nie może również ucierpieć wskutek okoliczności, że w łańcuchu dostaw, którego część stanowią owe transakcje, o czym podatnik ten nie wie lub nie może wiedzieć, inna transakcja, wcześniejsza lub późniejsza w stosunku do tej, która została dokonana przez niego, stanowi oszustwo w zakresie podatku VAT". Wobec tego podatnik, który nie wie lub nie może wiedzieć, że bierze udział w oszustwie podatkowym, powinien mieć możliwość skorzystania z prawa do odliczenia. Wskazuje się bowiem, że dochował należytej staranności i sprawdzał swoich kontrahentów. Nie może jednak brać odpowiedzialności za wcześniejsze czy też późniejsze dostawy poszczególnych podatników biorących udział w łańcuchu dostaw.

W późniejszym wyroku w sprawach połączonych C-439/04 Axel Kittel oraz C-440/04 Recolta Recycling SPRL ${ }^{13}$ TSUE odniósł się również do prawa do odliczenia w kontekście oszust podatkowych. Pierwszy z podatników, który reprezentowany był przez syndyka masy upadłościowej - Axel Kittel, był świadomym uczestnikiem

tems Ltd v. Commissioners of Customs, http://curia.europa.eu/juris/liste. jsf?language =en\&num=C-354/03 (dostęp: 01.06.2016 r.).

${ }^{13}$ Wyrok TSUE $z$ dnia 6 lipca 2006 r. w sprawach połączonych C-439/04 Axel Kittel oraz C-440/04 Recolta Recycling SPRL, http://eur-lex.europa.eu/legalcontent/PL/TXT/?uri=CELEX\%3A62004CJ0439 (dostęp: 01.06.2016 r.). 
oszustwa. Natomiast drugi - Recolta Recycling, nabył towary od podatnika, który dokonywał oszustw podatkowych. Oba przypadki opierały się na mechanizmie sprzedaży towarów i niewpłacania za te transakcje podatku VAT do organów skarbowych. W związku z tym organy podatkowe odmówiły podatnikom prawa do odliczenia podatku, ,powołując się na przepis prawa cywilnego, zgodnie z którym zobowiązane pozbawione causa albo oparte na wadliwej lub sprzecznej $z$ prawem causa nie wywołuje skutków prawnych"14. Zgodnie $z$ prawem cywilnym nie były one ważne, a co za tym idzie, organy podatkowe uznały, że nie występuje tutaj dostawa towarów, a w związku $z$ tym nie ma prawa do odliczenia podatku naliczonego. TSUE nie zgodził się z poglądem organów skarbowych i wskazał, że prawo do odliczenia jest integralną częścią podatku VAT i nie może zostać ograniczone, poza wyjątkami ściśle określonymi. Mechanizm podatku VAT opiera się bowiem na zasadzie neutralności. Wobec tego TSUE podkreślił w tym wyroku w pkt 37, że „Komisja Wspólnot Europejskich utrzymuje, że dostawa towarów na rzecz podatnika, który zawarł umowę $\mathrm{w}$ dobrej wierze, nie wiedząc o oszustwie podatkowym popełnionym przez sprzedawcę, jest dostawą towarów w rozumieniu art. 5 ust. 1 IV Dyrektywy VAT". Ponadto w pkt 52 wyroku wskazał, że „podmioty gospodarcze podejmujące wszelkie możliwe działania, których podjęcia można się od nich w sposób uzasadniony domagać celem zapewnienia, że realizowane przez nie transakcje nie stanowią części łańcucha, obejmującego transakcję dotkniętą oszustwem w podatku VAT, powinny móc powołać się na ich legalność, bez ryzyka utraty prawa do odliczenia naliczonego podatku VAT" ${ }^{15}$.

Ponadto TSUE $\mathrm{w}$ wyroku tym wskazał $\mathrm{w}$ pkt 56, iż podatnik, „który wiedział lub powinien był wiedzieć, że nabywając towar lub usługę, uczestniczy w transakcji stanowiącej element przestępstwa w dziedzinie podatku VAT, należy bowiem $z$ punktu widzenia

14 J. Martini, Ł. Karpiesiuk, VAT w orzecznictwie Europejskiego Trybunału Sprawiedliwości, Warszawa 2007, s. 516.

${ }^{15}$ Zob. także podobnie wyrok TSUE $z$ dnia 11 maja 2006 r. w sprawie C384/04 Federation of Technological Industries, http://curia.europa.eu/juris/ liste.jsf?language $=\mathrm{en} \&$ num $=\mathrm{C}-384 / 04$ (dostęp: 01.06.2016 r.). 
dyrektywy 2006/112 uznać za wspólnika w tym przestępstwie, niezależnie od tego, czy uzyskuje on korzyści z dalszej sprzedaży owych towarów lub świadczenia usług w ramach dokonywanych przez siebie transakcji”.

W kluczowym wyroku w zakresie należytej staranności sąd wypowiedział się $\mathrm{w}$ połączonych sprawach C-80/11 Mahagében kft i C-142/11 Péter Dávid ${ }^{16}$. Sprawa tyczyła się dwóch podmiotów: spółki Mahagében oraz pana Pétera Dávida. Pan Dávid to przedsiębiorca, który zlecał roboty budowlane swoim podwykonawcom, m.in. panu Mate. Organy podatkowe w toku kontroli doszły, że pan Mate nie świadczył usług i zlecał je dalej swoim podwykonawcom, ale wystawiał mimo to faktury za usługi budowlane. Natomiast w sprawie spółki Mahagében, która kupowała towary w postaci kłód akacjowych od spółki Rómahegy-Kert, organy podatkowe ustaliły, że spółka Rómahegy-Kert nie posiadała odpowiednich zapasów sprzedawanego towaru.

W obu sprawach nie zostały zakwestionowane okoliczności, że dostawa towarów miała miejsce, a usługi budowlane zostały wykonane. Nie było również wątpliwości, że faktury dokumentowały rzeczywiste transakcje. Organy podatkowe uznały jednak zgodnie z przepisami węgierskimi oraz obowiązującą praktyką, że transakcje doszły do skutku, jednak nie były okolicznościami, które wystarczają, aby podatnik mógł skorzystać z prawa do odliczenia podatku VAT.

W wyroku tym, podobnie jak w sprawach połączonych C-439/04 Axel Kittel oraz C-440/04 Recolta Recycling SPRL, Trybunał wskazał w pkt 53, że „zgodnie $z$ orzecznictwem Trybunału, jeżeli podmiot gospodarczy podjął wszelkie działania, jakich można od niego w sposób uzasadniony oczekiwać, w celu upewnienia się, że transakcje, w których uczestniczy, nie wiążą się z przestępstwem, czy to w zakresie podatku VAT, czy w innej dziedzinie, może on domniemywać legalność tych transakcji bez ryzyka utraty prawa do odliczenia naliczonego podatku VAT".

${ }^{16}$ Wyrok TSUE $z$ dnia 21 czerwca 2012 r. w połączonych sprawach C-80/11 Mahagében kft i C-142/11 Péter Dávid. 
Natomiast w wyroku TSUE w sprawie C-409/04 Teleos plc i in. ${ }^{17}$ Trybunał rozpoznał sprawę spółki brytyjskiej sprzedającej spółce hiszpańskiej telefony komórkowe, które następnie trafiały na rynek francuski i hiszpański. Telos zostawiała zgodnie $z$ umową telefony komórkowe w magazynie. Transportem zajmowała się spółka hiszpańska, która miała dokumenty potwierdzające wywóz (list przewozowy CMR). Organy podatkowe jednak zakwestionowały listy przewozowe CMR, przewoźnicy bowiem tam wykazani albo nie istnieli albo nie zajmowali się przewozem telefonów komórkowych. Wobec tego organy podatkowe doszły do wniosku, że telefony komórkowe nigdy nie opuściły Wielkiej Brytanii i nigdy nie miały miejsca wewnątrzwspólnotowe dostawy towarów. Organy podatkowe nakazały zapłacenie podatku VAT od Teleos, która brała udział w oszustwie podatkowym.

W rozstrzygnięciu tego wyroku TSUE w pkt 66 podkreślił, że „okoliczności, że dostawca działał w dobrej wierze, że przedsięwziął wszelkie racjonalne środki, jakie pozostawały w jego mocy oraz że jego udział w oszustwie podatkowym jest wykluczony, stanowią czynniki istotne dla ustalenia możliwości zobowiązania go do rozliczenia podatku VAT a posteriori”.

Wskazane wyroki odnoszą się do generalnie do prawa odliczenia podatku VAT w przypadku uczestniczenia w karuzeli podatkowej. W przypadku zawarcia transakcji, w której podatnik nie wiedział i nie miał świadomości uczestniczenia w oszustwie podatkowym, podatnik ma prawo do odliczenia podatku naliczonego VAT.

W orzeczeniach tych TSUE wskazuje przede wszystkim na przepisy Dyrektywy VAT, a zwłaszcza art. 167, 166 lit. a oraz art. 178 lit. a, które sprzeciwiają się praktyce krajowej odnoszącej się do odmowy możliwości odliczenia podatku VAT przez podatnika. Dotyczy to przypadków, gdy organ podatkowy znalazł nieprawidłowości, ale nie udowodnił podatnikowi, że wiedział lub powinien był wiedzieć, że transakcja służyła przestępstwu ${ }^{18}$.

17 Wyrok TSUE $z$ dnia 27 września 2007 r., sygn. C-409/04 Teleos plc i in., http://curia.europa.eu/juris/document/document.jsf?docid=63505\&doclan$\mathrm{g}=\mathrm{PL}$ (dostęp: 01.06.2016 r.).

${ }^{18}$ M. Militz, Dobra wiara w VAT - stosowanie regut wskazanych przez Trybu- 
„Z powyższych orzeczeń należy wyciągnąć wniosek, że jeżeli dostawca towarów nie mógł dowiedzieć się nawet przy zachowaniu należytej staranności sumiennego kupca, że zasady dokonywania dostaw były inne niż wynikało to np.: $\mathrm{z}$ posiadanych dokumentów i ustaleń (kontraktów), i w sposób oczywisty postępował zgodnie $\mathrm{z}$ standardami działania $\mathrm{w}$ dobrej wierze oraz zachowania staranności, to nie może ponosić on konsekwencji nieuczciwego działania nabywcy" 19 .

W literaturze wskazuje się, że „w przypadku, gdyby okoliczności transakcji powinny ewidentnie wzbudzić ostrożność podatników, nawet gdyby obiektywnie nie posiadali wiedzy o oszustwie podatkowym, prawo do odliczenia nie powinno przysługiwać. Natomiast z drugiej strony nie można nadużywać koncepcji należytej staranności poprzez oczekiwania w stosunku do podatników do podejmowania rozległych czynności weryfikujących kontrahenta"20.

TSUE wywiódł ponadto $z$ przedstawionych wyroków, iż zgodnie $\mathrm{z}$ zasadą neutralności podatku VAT prawo do odliczenia może być wykonywane niezwłocznie w stosunku do wszelkich kwot podatku naliczonych przy nabyciu towarów i usług przez podatnika VAT w związku z jego czynnościami opodatkowanymi. Tylko w wyjątkowych sytuacjach organy podatkowe mogą zakwestionować prawo do odliczenia podatku naliczonego.

Trybunał wyakcentował również w wskazanych wyrokach, że organy podatkowe mają obowiązek dokładnie sprawdzić transakcje, czy rzeczywiście podatnik nieświadomie brał udział w oszustwach podatkowych. W wyroku C-642/11 (Stroj trans EOOD) TSUE ${ }^{21}$ w pkt 37 odniósł się do tej kwestii i uwypuklił, iż „prawo Unii nie wyklucza jednak możliwości kontroli przez właściwy organ rze-

nał Sprawiedliwości $w$ krajowej praktyce, w: Polskie prawo podatkowe a prawo unijne. Katalog rozbieżności, red. B. Brzeziński, D. Dominik-Ogińska, K. Lasiński-Sulecki, A. Zalasiński, Warszawa 2016, s. 46-47.

${ }^{19}$ M. Militz, D. Dominik-Ogińska, M. Bącal, T. Siennicki, Zasady prawa unijnego $w$ VAT, Warszawa 2013, s. 90.

${ }^{20}$ J. Martini, Ł. Karpiesiuk, op.cit., s. 531.

${ }^{21}$ Wyrok TSUE z dnia 31 stycznia 2013 r. w sprawie C-642/11 Stroj trans EOOD, http://curia.europa.eu/juris/document/document.jsf?doci$\mathrm{d}=133243 \&$ doclang=PL (dostęp: 01.06.2016 r.). 
czywistego charakteru transakcji wskazanych przez podatnika na fakturze i ewentualnej korekty wysokości zobowiązania podatkowego wynikającej $z$ deklaracji podatnika. Wynik takiej kontroli stanowi, podobnie jak deklaracja i zapłata przez wystawcę faktury wyszczególnionego na niej podatku VAT, jedną z okoliczności, jaką sąd krajowy winien wziąc pod uwagę przy ocenie rzeczywistego charakteru konkretnej transakcji opodatkowanej będącej podstawą prawa odbiorcy faktury do odliczenia podatku”.

Zdaniem Trybunału we wskazanych wyrokach podatnicy podejmujący wszelkie środki w postaci: sprawdzenia w systemach, czy podatnik jest czynnym podatnikiem VAT, czy opłaca on podatek VAT, jak długo istnieje na rynku, opinii o sprzedawanych towarach w celu ustalenia, że podejmowane przez nich transakcje nie stanowią elementu popełnianych przez inne podmioty oszustw, muszą mieć możliwość odliczenia podatku VAT naliczonego w związku $z$ tymi umowami, nie ma bowiem znaczenia, czy transakcje te stanowią element obejścia przepisów o VAT lub innego nadużycia popełnianego przez osoby trzecie, w tym także bezpośredniego sprzedawcę.

\subsection{Orzeczenia polskich sądów administracyjnych}

Polskie sądy administracyjne w swoich orzeczeniach powołują się na wyroki TSUE. NSA oraz WSA podkreślają, że działanie podatnika musi być usprawiedliwione $\mathrm{w}$ danych okolicznościach sprawy, że działał zgodnie $z$ przepisami prawa. $W$ orzeczeniach ${ }^{22}$ podkreśla się, że dobra wiara jest oparta na przesłankach obiektywnych, wywodzących się ze stosunku będącego podstawą i przyczyną konkretnego stanu faktycznego.

Polskie sądy administracyjne, rozpatrując sprawy związane $z$ prawem do odliczenia podatku VAT, muszą na podstawie zgromadzonego przez organy podatkowe materiału dowodowego określić, czy dany podmiot wiedział lub powinien wiedzieć, że bierze

22 Wyrok NSA z dnia 18 stycznia 2012 r., sygn. II GSK 1209/11, http://orzeczenia. nsa.gov.pl/doc/2ED5F78826 (dostęp: 10 czerwca 2016 r.). 
udział w oszustwie podatkowych. Wobec tego w wielu orzeczeniach zarówno NSA, jak i WSA dokładnie określają, co jest rozumiane przez dobrą wiarę i należytą staranność. W zakresie dobrej wiary polskie sądy administracyjne przyjęły, że polega na usprawiedliwionym w danych okolicznościach przekonaniu, że podatnik miał prawo skorzystania $z$ prawa do odliczenia, gdyż działał zgodnie z prawem. W wyroku WSA w Gdańsku z dnia 31 marca 2016 r., sygn. I SA/Gd 1453/15²3, w którym sąd podkreślił, że „dobra wiara jest oparta na przesłankach obiektywnych, wywodzących się ze stosunku będącego podstawą i przyczyną konkretnego stanu faktycznego. W dobrej wierze jest ten, kto powołuje się na pewne prawo lub stosunek prawny, mniemając, że to istnieje, choćby mniemanie to było błędne, jeżeli tylko błędność mniemania należy w danych okolicznościach uznać za usprawiedliwioną. W złej wierze jest ten, kto powołując się na pewne prawo lub stosunek prawny, wie, że owo prawo lub stosunek prawny nie istnieje, albo też wprawdzie tego nie wie, ale jego braku wiedzy w danych okolicznościach nie można uznać za usprawiedliwiony”.

W jednym $z$ wcześniejszych wyroków NSA $z$ dnia 18 stycznia 2012 r., sygn. II GSK 1209/11 NSA powołał się na kwestie wskazaną przez sąd I instancji (WSA), że „w dobrej wierze jest ten, kto, powołując się na określone prawo lub stosunek prawny, jest przekonany o przysługiwaniu mu tego prawa lub istnieniu określonego stosunku prawnego, gdy w rzeczywistości jest on w błędzie co do istotnego stanu rzeczy. Aby przyjąć dobrą wiarę, błędne przekonanie o istnieniu prawa lub stosunku prawnego, musi być w konkretnych okolicznościach usprawiedliwione. O usprawiedliwionym przekonaniu można mówić, gdy dana osoba nie wie o okolicznościach decydujących o zastosowaniu normy prawnej uzależniającej istnienie skutku prawnego od dobrej lub złej wiary oraz gdy nie mogła się ona o tym dowiedzieć mimo zachowania należytej staranności”. Dalej w uzasadnieniu do wskazanego wyroku NSA podkreślił, że „w dobrej wierze jest ten, kto powołuje się na pewne prawo lub stosunek prawny, mniemając, że to istnieje, choćby mniemanie

${ }^{23}$ Wyrok WSA w Gdańsku z dnia 31 marca 2016 r., I SA/Gd 1453/15, http://orzeczenia.nsa.gov.pl/doc/56B380A2D8 (dostęp: 10.06.2016 r.). 
to było błędne, jeżeli tylko błędność mniemania należy w danych okolicznościach uznać za usprawiedliwioną".

Natomiast w zakresie należytej staranności w jednym $z$ wyroków $\mathrm{NSA}^{24}$ określił, że każda sprawa jest inna, wobec tego od organów podatkowych wymaga się ,zbadania przestrzegania przez podatnika zasad należytej staranności kupieckiej, gdyż jak stwierdził TSUE jeżeli istnieją przesłanki, by podejrzewać istnienie nieprawidłowości lub przestępstwa, przezorny przedsiębiorca powinien, zależnie od okoliczności konkretnego wypadku, zasięgnąć informacji na temat podmiotu, u którego zamierza nabyć towary lub usługi, w celu upewnienia się co do jego wiarygodności. Przede wszystkim istotnym jest, aby same okoliczności towarzyszące transakcji wskazywały, że nabywający towar lub usługę podatnik wykazał w niej staranność wymaganą w obrocie danym towarem (usługa), czyniącą tę transakcję przejrzystą (transparentną)" 25 .

W innym $z$ wyroków NSA $z$ dnia 30 maja 2014 r., sygn. I FSK 1395/13 sąd odniósł się do zagadnienia odliczenia podatku VAT z faktur na zakup paliwa. NSA za sądem I instancji (WSA) podkreślił, że podatnik powinien nie tylko posiadać oświadczenie kontrahenta o pochodzeniu towarów, ale powinien rzeczywiście sprawdzić, skąd dany towar pochodzi. Wobec tego w wyroku dokładnie wskazano, „że uzyskanie przez skarżącego dowody, dotyczące statusu kontrahentów w postaci zaświadczenia o wpisie do ewidencji działalności gospodarczej, zarejestrowania jako podatnika podatku od towarów i usług, decyzji o nadaniu numeru NIP i REGON, przy braku dokumentów potwierdzających, że nabywany towar był olejem napędowym (świadectwa jakości, dokumentów przewozowych czy przewoźnika) nie mogły świadczyć o tym, iż skarżący dochował ze swej strony należytej staranności. Mając bowiem na względzie

${ }^{24}$ Wyrok NSA z dnia 26 czerwca 2014 r., sygn. I FSK 776/13, http://orzeczenia.nsa.gov.pl/doc/OADBFBBFE1 (dostęp: 10.06.2016 r.).

${ }^{25}$ Por. wyrok NSA z dnia 14 marca 2014 r., sygn. I FSK 436/12 http:// orzeczenia.nsa.gov.pl/doc/CODE769E21 (dostęp: 10.06.2016 r.); wyrok NSA z dnia 26 czerwca 2012 r., sygn. I FSK 1200/11, http://orzeczenia.nsa.gov.pl/ doc/EB5F8C03A7 (dostęp: 10 czerwca 2016 r.); wyrok WSA $z$ dnia 18 listopada 2015 r., sygn. I SA/Łd 837/15 http://orzeczenia.nsa.gov.pl/doc/EE5D5A8D8B (dostęp: 10.06. 2016 r.). 
przedmiot dokonywanego zakupu, fakt prowadzenia działalności gospodarczej od 1991 r., cenę towaru, sposób oferowania jego sprzedaży i dostawy, skarżący powinien podjąć dodatkowe działania mające na celu upewnienie się co do legalności nabywanego paliwa (najlepiej w siedzibie dostawcy i zażądać przedstawienia koncesji na obrót paliwami)". Zdaniem Sądu, samo oświadczenie dostawcy o legalności pochodzenia towaru w takich okolicznościach jego dostawy było niewystarczające. Wyraźnie widoczne jest, że posiadanie dokumentów odnośnie do kontrahenta, istnieje jego działalności od wielu lat i posiadanie oświadczenie o pochodzeniu paliwa to za mało. Podatnik powinien dokładnie wiedzieć, że branża paliwowa jest bardzo wrażliwa na oszustwa podatkowe (karuzele podatkowe) i podatnik może brać udział w łańcuchu dostaw. Powinien wobec tego podjąć szczególne środki ostrożności przy kupnie paliwa od swojego kontrahenta. Zaufanie i znajomość podmiotu, od którego podatnik kupił towar, nie wystarczy.

Ponadto w innym orzeczeniu $\mathrm{WSA}^{26}$ wyeksponował, że podatnik powinien w konkretnych okolicznościach, „zasięgnąć informacji na temat podmiotu, u którego zamierza nabyć towary lub usługi, w celu upewnienia się co do jego wiarygodności. Przede wszystkim istotnym jest, aby same okoliczności towarzyszące transakcji wskazywały, że nabywający towar lub usługę podatnik wykazał w niej staranność wymaganą w obrocie danym towarem (usługą), czyniącą tę transakcję przejrzystą (transparentną)".

Orzeczenia polskich sądów administracyjnych, podobnie jak wyroki TSUE, rekomendują pewne działania podatnika, polegające na sprawdzeniu kontrahenta, ale i towaru, który od niego pochodzi. Każdy stan faktyczny jest inny i działanie podejmowane przez podatnika też powinno być zindywidualizowane. Ma to szczególne znaczenie w branżach wrażliwych, m.in. obrót złomem, paliwami, elektroniką. W nich podatnicy powinni zachować zwłaszcza należytą staranność i dobrą wiarę.

Ponadto podkreśla się, że sądy krajowe nie muszą w każdej sprawie występować do TSUE $z$ pytaniem prejudycjalnym, jeśli

${ }^{26}$ Wyrok WSA z dnia 18 listopada 2015 r., sygn. I SA/Łd 837/15 http:// orzeczenia.nsa.gov.pl/doc/EE5D5A8D8B (dostęp: 10 czerwca 2016 r.). 
dane zagadnienie zostało już wyjaśnione poprzez wcześniejsze wyroki, zgodnie $z$ tzw. doktryną acte éclaire. TSUE dokonuje bowiem wiążącej wykładni przepisów prawa unijnego tam, gdzie wymagana są wyjaśnienia, nie rozstrzygając sporów podatników, które należą do sądów krajowych.

\section{Podsumowanie}

Przepisy zarówno polskie, jak i unijne nie definiują pojęć „należyta staranność” oraz „dobra wiara”. Oba pojęcia to tzw. klauzule generalne, które zdefiniowane zostały na potrzeby prawa do odliczenia podatku VAT przez TSUE.

Zapewniają one przy dokonywaniu konkretnej oceny stanu faktycznego tzw. luz interpretacyjny, który pozwala uwzględnić kryteria pozaprawne mające znaczenie $\mathrm{w}$ funkcjonowaniu społeczeństwa. Dzięki wyjaśnieniu tych pojęć podatnik może skorzystać z prawa do odliczenia podatku VAT. Zaprezentowane orzecznictwo wprowadziło do systemu VAT klauzulę słusznościową, która uważa dobrą wiarę za wentyl bezpieczeństwa. Daje to możliwość uwzględnienia zdania podatnika i nadania mu uprawnień w systemie VAT, m.in. w zakresie prawa do odliczenia czy zastosowania zwolnienia, w zakresie wystąpienia szczególnych okoliczności, które na to nie pozwalają ${ }^{27}$.

„Podatnik działający w dobrej wierze, a zwłaszcza pod warunkiem, że nie brał udziału w nieprawidłowościach i podjął wszelkie środki zapobiegawcze rozsądnie wymagane, nie powinien ponosić odpowiedzialności za oszustwa osób trzecich"28. Wobec tego podatnik rozumie należytą staranność jako zwykłą kupiecką, zwyczajowo przyjętą staranność, która związana jest z przekonaniem, że towar czy też usługa nie jest dokonana/wykonana przez oszusta. Podatnik powinien dochować minimum staranności i dobrej wiary przy

27 D. Dominik-Ogińska, Dobra wiara $w$ podatku od wartości dodanej $w$ orzecznictwie Trybunału Sprawiedliwości Unii Europejskiej (3), „Przegląd Podatkowy” 2013, nr 9, s. 26.

${ }^{28}$ M. Militz, D. Dominik-Ogińska, M. Bącal, T. Siennicki, op.cit., s. 89. 
sprawdzaniu kontrahenta, a nie za organy podatkowe poszukiwać nieuczciwych przedsiębiorców.

Wskazane orzeczenia pokazują, że zarówno TSUE, jak i polskie sądy administracyjne podkreślają, że podmiot gospodarczy, który podjął wszelkie działania, jakich można od niego w sposób uzasadniony oczekiwać, w celu upewnienia się, że transakcje, w których uczestniczy, nie wiążą się z przestępstwem, powinien mieć możliwość skorzystania $z$ prawa do odliczenia. Zapewnia to jednolitość interpretacji przepisów prawa wspólnotowego, która musi być tak samo rozumiana niezależnie od sprawy, sądu czy też państwa członkowskiego.

Warto na końcu podkreślić, że pojęcia należytej staranności i dobrej wiary moim zdaniem nie powinno być, ani obecnie, ani w przyszłości. Spowodować to bowiem może zawężenie pojęciowe i może być również rozumiane zarówno przez organy, jak i sądy w sposób zbyt restrykcyjny. Organy podatkowe i sądy administracyjne powinny rozumieć oba pojęcia w taki sposób, aby móc dostosować do konkretnego stanu faktycznego.

\section{STRESZCZENIE}

Należyta staranność i dobra wiara w orzecznictwie

Trybunału Sprawiedliwości Unii Europejskiej oraz polskich sądów administracyjnych

Artykuł przedstawia problem należytej staranności oraz dobrej wiary w podatku od towarów i usług (podatku od wartości dodanej w przepisach unijnych) na podstawie orzecznictwa Trybunału Sprawiedliwości Unii Europejskiej oraz polskich sądów administracyjnych.

Trybunał Sprawiedliwości Unii Europejskiej, a za nim polskie sądy administracyjne wskazały, że zarówno należyta staranność, jak i dobra wiara stanowią podstawę do odliczenia podatku należnego w podatku od towarów i usług. W wielu orzeczeniach wskazano, że nie można odmówić prawa do odliczenia podatnikowi, który spełnienia wszystkie przesłanki do odliczenia podatku, w tym dochował należytej staranności i dobrej wiary, by móc skorzystać z prawa do odliczenia.

Dobra wiara oznacza w uproszczeniu, iż podatnik działa jako podatnik uczciwy i rzetelny. Natomiast należyta staranność oznacza dochowa- 
nie rzetelności przedsiębiorcy w obrocie gospodarczym i nieuwikłanie się w oszustwa podatkowe.

Artykuł przedstawia jedynie zwalczanie oszust podatkowych i nie skupia się na samym mechanizmie karuzel podatkowych.

Słowa klucze: dobra wiara; należyta staranność; podatnik; organ podatkowy; wyrok; karuzela podatkowa; oszustwo podatkowe

\section{SUMMARY}

Due diligence and good faith in reference to the rulings Court of Justice of the European Union and polish administrative courts

This article discusses an issue of due diligence and good faith in reference to tax on goods and services (value added tax in accordance with EU regulations) considering the rulings Court of Justice of the European Union and Polish administrative courts.

The Court of Justice of the European Union followed by Polish administrative courts pointed out that due diligence as well as good faith pose as a basis for due tax deduction while speaking of tax on goods and services. According to many rulings, the right for tax deduction cannot be denied a tax payer who meets all of the conditions including due diligence and good faith thus shall have this right granted.

In simple terms, good faith means that a tax payer performs his/her tax duties in a just and honest manner. Due diligence, on the other hand, consists in entrepreneur's making sure that all of the business transactions are reliable and his/her not taking part or being a part of any tax fraud.

This article deals only with fighting against tax frauds and will not touch upon the mechanisms of tax carrousels.

Key words: good faith; due diligence; tax payer; ruling; tax authority; tax carrousel; tax fraud

\section{BIBLIOGRAFIA}

Banaszczyk Z., Granecki P., O istocie należytej staranności, „Palestra” 2002, nr 7-8. 
Doliwa K., Dobra wiara jako wyrażenie języka prawnego, „Monitor Prawniczy” 2008, nr 6.

Dominik-Ogińska D., Dobra wiara $w$ podatku od wartości dodanej $w$ orzecznictwie Trybunału Sprawiedliwości Unii Europejskiej (1), „Przegląd Prawa Podatkowego" 2013, nr 7.

Dominik-Ogińska D., Dobra wiara $w$ podatku od wartości dodanej $w$ orzecznictwie Trybunału Sprawiedliwości Unii Europejskiej (3), „Przegląd Podatkowy" 2013, nr 9.

Machnikowski P., w: Kodeks cywilny. Komentarz, red. E. Gniewek, P. Machnikowski, Warszawa 2013.

Martini J., Karpiesiuk Ł., VAT w orzecznictwie Europejskiego Trybunału Sprawiedliwości, Warszawa 2007.

Militz M., Dobra wiara $w$ VAT - stosowanie reguł wskazanych przez Trybunat Sprawiedliwości $w$ krajowej praktyce, w: Polskie prawo podatkowe a prawo unijne. Katalog rozbieżności, red. B. Brzeziński, D. DominikOgińska, K. Lasiński-Sulecki, A. Zalasiński, Warszawa 2016.

Militz M., Nowe aspekty badania dobrej wiary u nabywców paliw, „Przegląd Podatkowy" 2014, nr 8.

Militz M., Dominik-Ogińska D., Bącal M., Siennicki T., Zasady prawa unijnego $w$ VAT, Warszawa 2013.

Sośniak M., Należyta staranność, Katowice 1980. 
